\title{
PENGARUH KONSENTRASI JAHE DAN KONSENTRASI STABILIZER GUAR GUM TERHADAP SIFAT FISIK DAN ORGANOLEPTIK ES KRIM JAHE
}

\author{
(The Effect of Ginger Concentration and Concentration of Guar Gum \\ Stabilizers on Physic and Organoleptic Properties of Ginger Ice Cream)
}

\author{
Thresia Margareth Harsanto $^{a_{*}}$ dan Adrianus Rulianto Utomo ${ }^{a}$
}

aFakultas Teknologi Pertanian, Universitas Katolik Widya Mandala Surabaya, Indonesia

${ }^{*}$ Penulis korespondensi

Email: thresiamargareth@yahoo.co.id

\begin{abstract}
Ginger is one of the kind of spice plants used by housewives as a spice for cooking. Ginger contains 0,25$3,3 \%$ of essential oils which gives a distinctive aroma of ginger. Typical scent and ginger flavor makes ginger potentially used as a flavoring agent on ice cream. Ice cream is a diary product with the addition of flavorings or sweeteners and served in semi-frozen form. The ice cream quality improvement can be done with the addition of a stabilizers, that is guar gum. Guar gum swells and or dissolves in a polar solvent and forms a strong hydrogen bonds due to the presence of hydroxyl groups in guar gum molecules. The aim of this research is to know the effect of ginger concentration and the concentration of guar gum stabilizer on physical and organoleptic properties of ginger ice cream. The parameters measured in this study are physical parameters including melting rate, overrun percent and the organoleptic parameters are taste and mouthfeel. The design used was Randomized Block Design (RBD) with two factors. Each factor consisted of 3 levels i.e. $20 \%, 35 \%$ and $50 \%$ on the concentration of ginger and 0,2\%, 0,4\% and 0,6\% on guar gum concentration factor with 3 replications. The data were analyzed statistically to find out if there was any effect of ginger concentration and guar gum stabilizer concentration on parameter using ANOVA test at $\alpha=5 \%$. If the effect of treatment on tested parameter are real then continued with the DMRT test at $\alpha=5 \%$ to know the treatment is significantly different. The results showed that there was an effect of different concentrations of ginger and guar gum stabilizer on ginger ice cream. The higher concentrations of ginger and guar gum concentrations lead to decreased melting and overrun rates. The highest taste of ginger ice cream in P1K2 treatment and mouthfeel highest in P2K3 treatment.
\end{abstract}

Keywords: Ginger, ice cream, guar gum

\begin{abstract}
ABSTRAK
Jahe adalah salah satu tanaman jenis rempah-rempah yang banyak dimanfaatkan oleh ibu-ibu rumah tangga sebagai bumbu untuk memasak. Jahe memiliki kandungan minyak atsiri sebesar $0,25-3,3 \%$ yang menimbulkan aroma khas jahe. Aroma dan rasa jahe yang khas membuat jahe potensial digunakan sebagai pemberi flavor pada es krim. Es krim merupakan produk olahan susu dengan penambahan perasa atau pemanis dan disajikan dalam bentuk semi beku. Peningkatan kualitas es krim dapat dilakukan dengan penambahan bahan penstabil, yaitu guar gum. Guar gum membengkak dan atau larut dalam pelarut polar dan membentuk ikatan hidrogen yang kuat dikarenakan adanya gugus hidroksil dalam molekul guar gum. Tujuan penelitian ini adalah mengetahui pengaruh konsentrasi jahe dan konsentrasi stabilizer guar gum terhadap sifat fisik dan organoleptik es krim jahe. Parameter yang diukur adalah parameter fisik meliputi laju pelelehan, persen overrun dan parameter organoleptik yaitu rasa dan mouthfeel. Rancangan yang digunakan adalah Rancangan Acak Kelompok (RAK) dengan dua faktor.
\end{abstract}


Masing-masing faktor terdiri dari 3 level yaitu 20\%,35\% dan 50\% pada faktor konsentrasi jahe dan 0,2\%, $0,4 \%$ dan $0,6 \%$ pada faktor konsentrasi guar gum dengan 3 kali ulangan. Data dianalisa secara statistik untuk mengetahui apakah terdapat pengaruh konsentrasi jahe dan konsentrasi stabilizer guar gum terhadap parameter menggunakan uji ANOVA pada $\alpha=5 \%$. Jika pengaruh perlakuan terhadap uji parameter teruji nyata maka dilanjutkan dengan Uji DMRT pada $\alpha=5 \%$ untuk mengetahui perlakuan yang berbeda nyata. Hasil penelitian menunjukkan ada pengaruh perbedaan konsentrasi jahe dan stabilizer guar gum pada es krim jahe. Semakin tinggi konsentrasi jahe maupun konsentrasi guar gum menyebabkan penurunan laju leleh dan overrun. Kesukaan rasa es krim jahe paling tinggi pada perlakuan P1K2 dan kesukaan mouthfeel es krim jahe paling tinggi pada perlakuan P2K3.

Kata kunci: Jahe, es krim, guar gum

\section{PENDAHULUAN}

Jahe (Zingiber officinale) telah lama dikenal dan tumbuh baik di Indonesia. Rimpang jahe juga mengandung minyak atsiri sebesar 0,25-3,3\%. Minyak atsiri ini menimbulkan aroma khas jahe dan terdiri atas beberapa jenis minyak terpenting yaitu zingiberene, curcumene dan philandren (Koswara dkk., 2012). Jahe umumya hanya dimanfaatkan sebagai bumbu masakan, campuran makanan atau minuman, obatobatan dan kosmetik (Ali et al., 2008 dalam Febriyanti dan Yunaita, 2015). Dengan rasa dan aroma yang khas, jahe potensial digunakan sebagai pemberi flavor pada es krim. Es krim adalah salah satu produk makanan beku yang dibuat dengan membekukan campuran produk susu, gula, penstabil, pengemulsi dan bahan-bahan lainnya yang telah dipasteurisasi dan dihomogenisasi untuk memperoleh konsistensi yang seragam. Pembentukan rongga udara pada pencampuran es krim hingga diperoleh pengembangan volume yang membuat es krim lebih ringan, tidak terlalu padat dan mempunyai tekstur yang lembut merupakan prinsip pembuatan es krim. Permasalahan yang sering timbul pada proses pembuatan es krim adalah tekstur yang tidak lembut, kecepatan meleleh yang cepat dan overrun yang rendah (Elisabeth dkk, 2007). Peningkatan kualitas es krim dapat dilakukan dengan penambahan bahan pembentuk gel (gelling agents) atau bahan penstabil. Salah satu bahan penstabil yang biasa digunakan pada pembuatan es krim adalah guar gum. Guar gum membengkak dan atau larut dalam pelarut polar dan membentuk ikatan hidrogen yang kuat. Aktivitas ikatan hidrogen guar gum dikarenakan adanya gugus hidroksil dalam molekul guar gum.

\section{BAHAN DAN METODE}

\section{Bahan dan Alat}

Bahan baku yang digunakan dalam penelitian ini adalah susu bubuk full cream "Dancow", susu skim bubuk merek "New Zealand", gula pasir merek "Gulaku", air mineral, telur ayam negeri atau ras, jahe gajah dan jahe emprit serta guar gum bubuk.

Alat yang digunakan untuk pembuatan es krim adalah pisau, blender (Miyako), panci aluminium ukuran besar dan sedang, kompor LPG, sendok, piring plastik, baskom aluminium, water jug 2L, timbangan digital dan analitis, homogenizer (Janke and Kunkel-IKA Labortecnik jenis Ultra Turrax T25 kecepatan 8.000-24.000 rpm), refrigerator, ice cream maker (Cuisinart), air blast freezer (QSS-63, suhu terendah $40^{\circ} \mathrm{C}$ ), wadah plastik dan label. Alat yang digunakan untuk analisa adalah cup plastik, stopwatch, saringan 14 mesh, baskom 
aluminium, sendok, timbangan digital dan analitis dan label.

\section{Rancangan Percobaan}

Rancangan penelitian yang digunakan adalah Rancangan Acak Kelompok (RAK) dengan dua faktor, yaitu faktor konsentrasi jahe dan faktor konsentrasi penstabil guar gum pada pembuatan es krim. Faktor konsentrasi jahe terdiri atas tiga level, yaitu P1(20\%), P2 (35\%) dan P3 (50\%), sedangkan konsentrasi stabilizer guar gum juga terdiri atas tiga konsentrasi, yaitu $\mathrm{K} 1$ $(0,2 \%)$, K2 $(0,4 \%)$ dan K3 $(0,6 \%)$. Pengulangan dilakukan sebanyak tiga kali.

Parameter yang diuji adalah parameter fisik dan organoleptik es krim jahe, meliputi: laju pelelehan, persen overrun dan organoleptik yaitu rasa dan mouthfeel. Data dianalisa secara statistik menggunakan uji ANOVA pada $\alpha=5 \%$ untuk mengetahui apakah perlakuan memberikan pengaruh nyata pada setiap parameter pengujian. Apabila hasil uji ANOVA menunjukan perbedaan nyata maka dilanjutkan dengan uji pembedaan untuk menentukan taraf perlakuan mana yang memberikan perbedaan nyata. Uji pembedaan dilakukan dengan Uji beda jarak nyata Duncan (Duncan's Multiple Range Test/DMRT) pada $\alpha=5 \%$.

\section{Pembuatan Es Krim Jahe}

Jahe gajah dan jahe emprit masingmasing dibersihkan terlebih dahulu kemudian ditimbang dan dihancurkan dengan blender menggunakan kecepatan 12.500 rpm selama 5 menit, kemudian ditimbang dan dibekukan. Pasta jahe gajah dan jahe emprit di-thawing hingga suhu ruang. Kemudian pasta dicampur dengan perbandingan $4: 1$, kemudian dilarutkan dengan air suhu $\pm 60^{\circ} \mathrm{C}$ dan disaring sehingga diperoleh sari jahe. Pengambilan $600 \mathrm{ml}$ sari jahe kemudian dicampur dengan susu full cream bubuk, susu skim bubuk, gula pasir, kuning telur dan guar gum. Kemudian adonan es krim dipasteurisasi pada suhu $71,7-75^{\circ} \mathrm{C}$ selama 15 detik. Kemudian dihomogenkan pada suhu $50^{\circ} \mathrm{C}$ dengan kecepatan $15.000 \mathrm{rpm}$ selama 3 menit. Adonan es krim didinginkan pada suhu ruang kemudian di-aging pada suhu $4^{\circ} \mathrm{C}$ selama 24 jam. Setelah aging adonan es krim di-churning selama 40 menit kemudian dikemas dan disimpan pada refrigerator selama 24 jam.

\section{Metode Analisa}

Laju Pelelehan (Guinard et al., 1997)

Uji daya leleh dilakukan dengan meletakkan $60 \mathrm{~g}$ es krim di atas saringan 14 mesh, pada bagian bawah saringan telah diberi wadah penampung yaitu beaker glass yang telah ditimbang beratnya. Wadah ini digunakan untuk menampung tetesan es krim setiap 5 menit hingga 1 jam sejak dikeluarkan dari freezer. Berat es krim yang leleh dikurangi dengan wadah penampung kosong.

Overrun (Jimenez-Florez et al, 1993)

Perhitungan overrun dilakukan dengan mencari berat adonan es krim dan es krim setelah churning.

$\%$ Overrun $=\frac{\text { massa es krim }- \text { massa adonan }(g)}{\text { massa adonan }(g)} \times 100 \%$

\section{Uji Organoleptik}

Pengujian organoleptik dilakukan dengan menggunakan metode Hedonic Scale Scoring. Kisaran skor yang diberikan dimulai dari 1-7, semakin tinggi nilai yang diberikan oleh panelis menunjukkan tingkat kesukaan panelis terhadap parameter produk yang diuji. Pengujian organoleptik dilakukan oleh 150 panelis tidak terlatih yaitu mahasiswa UNIKA Widya Mandala Surabaya (Kartika, 1988). Pengujian dilakukan dalam 3 tahap sesuai dengan jumlah ulangan penelitian. Tiap ulangan akan diujikan 450 cup es krim kepada 50 orang panelis.

\section{HASIL DAN PEMBAHASAN}

\section{Laju Pelelehan}

Pengujian daya leleh dilakukan pada suhu $26^{\circ} \mathrm{C}$. Hasil pengujian ANOVA $(\alpha=$ $5 \%)$ menunjukkan bahwa masing-masing perlakuan, konsentrasi jahe dan konsentrasi guar gum, menunjukkan adanya pengaruh 
Tabel 1. Hasil pengujian laju pelelehan es krim jahe ( $\mathrm{g} / \mathrm{menit})$

\begin{tabular}{|c|c|c|c|c|c|c|c|c|c|}
\hline \multirow[b]{2}{*}{ Parameter } & \multicolumn{7}{|c|}{ Perlakuan } & \multirow[b]{2}{*}{ P3K2 } & \multirow[b]{2}{*}{ P3K3 } \\
\hline & P1K1 & P1K2 & P1K3 & P2K1 & P2K2 & P2K3 & P3K1 & & \\
\hline $\begin{array}{l}\text { Laju pelelehan ( } \mathrm{g} / \\
\text { menit) }\end{array}$ & $0,9324^{9}$ & $0,741^{\mathrm{e}}$ & $0,5694^{c}$ & $0,8321^{f}$ & $0,6737^{d}$ & $0,4805^{b}$ & $0,6603^{d}$ & $0,4977^{\mathrm{b}}$ & $0,3927^{\mathrm{a}}$ \\
\hline Overrun (\%) & $46,78^{i}$ & $43,88^{f}$ & $39,30^{c}$ & $46,02^{h}$ & $42,97^{e}$ & $38,23^{b}$ & $45,22^{g}$ & $41,99^{d}$ & $37,41^{\mathrm{a}}$ \\
\hline Rasa & $5,32^{\mathrm{ab}}$ & $5,38^{a}$ & $5,31^{\mathrm{ab}}$ & $5,03^{\mathrm{ab}}$ & $5,13^{\mathrm{ab}}$ & $4,92^{b}$ & $4,50^{\mathrm{C}}$ & $3,98^{\mathrm{d}}$ & $4,02^{d}$ \\
\hline Mouthfeel & $4,16^{a}$ & $4,57^{\mathrm{abc}}$ & $4,77^{\mathrm{cd}}$ & $4,30^{\mathrm{ab}}$ & $4,68^{\mathrm{bcd}}$ & $5,00^{d}$ & $4,15^{\mathrm{a}}$ & $4,43^{\mathrm{abc}}$ & $4,55^{\mathrm{abc}}$ \\
\hline
\end{tabular}

Keterangan:

$\mathrm{P} 1 \mathrm{~K} 1=$ Konsentrasi jahe $20 \%$ : konsentrasi guar gum 0,2\%

$\mathrm{P} 1 \mathrm{~K} 2=$ Konsentrasi jahe $20 \%$ : konsentrasi guar gum 0,4\%

$\mathrm{P} 1 \mathrm{~K} 3=$ Konsentrasi jahe 20\% : konsentrasi guar gum 0,6\%

$\mathrm{P} 2 \mathrm{~K} 1=$ Konsentrasi jahe $35 \%$ : konsentrasi guar gum 0,2\%

P2K2 = Konsentrasi jahe 35\%: konsentrasi guar gum 0,4\%

$\mathrm{P} 2 \mathrm{~K} 3=$ Konsentrasi jahe $35 \%$ : konsentrasi guar gum 0,6\%

$\mathrm{P} 3 \mathrm{~K} 1=$ Konsentrasi jahe 50\% : konsentrasi guar gum 0,2\%

$\mathrm{P} 3 \mathrm{~K} 2=$ Konsentrasi jahe $50 \%$ : konsentrasi guar gum 0,4\%

P3K3 $=$ Konsentrasi jahe $50 \%$ : konsentrasi guar gum 0,6\%

nyata terhadap laju pelelehan es krim jahe. Semakin tinggi konsentrasi jahe dan guar gum yang digunakan menyebabkan daya leleh es krim menjadi lebih lambat. Menurut Muse dan Hartel (2004), laju leleh es krim dipengaruhi oleh beberapa faktor, seperti jumlah udara dalam es krim, kristal es yang terbentuk dan globula lemak yang terbentuk selama proses churning. Faktor-faktor tersebut dipengaruhi oleh viskositas adonan, semakin kental adonan maka es krim membutuhkan waktu yang lebih lama untuk menetes. Hal tersebut dikarenakan jarak komponen-komponen dalam matriks semakin rapat sehingga es krim lebih lama menetes bila dibandingkan es krim dari adonan yang encer. Semakin kental adonan, akan menghasilkan es krim yang semakin padat karena sedikitnya udara dalam es krim yang dapat masuk saat proses churning. Sehingga suhu beku es krim dapat bertahan lebih lama dan membuat es krim yang lebih padat tersebut menjadi lebih lama menetes. Jahe memiliki kandungan polisakarida seperti karbohidrat dan pati, sehingga saat proses pemanasan

terjadi proses gelatinisasi yang menyebabkan semakin banyak air bebas yang terperangkap. Pati yang mengikat dan memerangkap air dalam jumlah besar juga akan mencegah molekul air untuk bergerak bebas dan membentuk selaput untuk melindungi komponen es krim dari pengaruh suhu luar, serta membatasi mobilitas air pada emulsi. Kristal es dalam es krim terbentuk dari air yang terperangkap dalam pati yang tergelatinisasi, sehingga jarak molekul menjadi lebih rapat, adonan menjadi lebih sulit untuk mengalir, sehingga menurunkan kecepatan pelelehan es krim. Semakin banyak jumlah pati yang digunakan akan memperkecil laju pelelehannya. Begitu juga pada perlakuan konsentrasi penstabil guar gum dalam konsentrasi jahe yang sama, laju pelelehan menurun seiring dengan meningkatnya konsentrasi guar gum yang digunakan. Hal ini dikarenakan gugus hidroksil pada guar gum akan mengikat air sehingga adonan menjadi lebih viskos seiring meningkatnya konsentrasi guar gum. Menurut DeMan (1999), peningkatan viskositas akan mengurangi air bebas sehingga terjadi penurunan jumlah kristal es yang menyebabkan laju leleh menurun. Peningkatan viskositas juga meningkatkan retensi air lelehan untuk mengalir sehingga laju leleh menurun.

\section{Overrun}

Overrun pada skala industri rumah tangga berkisar antara $35-50 \%$ dan skala industri besar $70-80 \%$ (Susilorini dan Sawitri, 2006 dalam Hakim dan Chamidah, 
2013). Sedangkan overrun es krim pada penelitian ini berkisar antara 37,41\%$46,78 \%$. Hasil pengujian ANOVA $(\alpha=5 \%)$ menunjukkan bahwa terdapat pengaruh nyata perlakuan konsentrasi jahe dan konsentrasi guar gum terhadap overrun es krim yang dihasilkan. Overrun semakin menurun seiring dengan peningkatan konsentrasi jahe yang digunakan. Hal ini dikarenakan semakin meningkatnya konsentrasi jahe yang digunakan maka semakin tinggi kandungan polisakarida seperti pati dan karbohidrat. Pati dalam sari jahe sebesar $3,87 \%$ sedangkan karbohidrat total pada sari jahe sebesar 5,53\% (Goraya, 2017). Semakin tinggi kandungan polisakarida menghasilkan adonan yang semakin viskos dan berat yang menyebabkan terjadinya penghambatan dalam pengembangan volume adonan akibat udara semakin sulit terperangkap (Clarke, 2004). Pati pada umumnya memiliki gugus $-\mathrm{OH}$, dan bersifat hidrofilik sehingga dapat mengikat air (hidrasi) secara lemah antara molekul-molekul pati. Sedangkan saat pemanasan air akan terperangkap atau yang disebut proses gelatinisasi pati yang menyebabkan naiknya viskositas. Adonan es krim yang terlalu viskos dapat meningkatkan kerapatan ruang antar partikel menjadi semakin sempit. Hal ini menyebabkan udara sulit untuk masuk ke dalam adonan atau menembus permukaan adonan sehingga adonan menjadi tidak dapat mengembang secara maksimal. Selain itu semakin berat adonan dan seiring meningkatnya konsentrasi jahe membuat udara yang masuk kedalam adonan menjadi keluar lagi akibat aliran adonan yang mengisi ruang udara tersebut semakin berat sehingga gelembung udara dalam adonan lebih sedikit dan mengakibatkan nilai overrun menjadi menurun. Seiring meningkatnya konsentrasi guar gum, persentase overrun yang dihasilkan juga menurun. Bahan penstabil guar gum memiliki kemampuan untuk mempertahankan overrun es krim dengan menjaga stabilitas busa es krim. Guar gum dalam es krim menghambat pertumbuhan kristal es yang besar dengan memperlambat transfer massa di seluruh permukaan. Hal ini menunjukkan stabilitas yang baik selama siklus beku hingga mencair sehingga mampu mempertahankan overrun es krim (Kawamura, 2008 dalam Padaga dkk, 2012). Semakin tinggi konsentrasi guar gum, maka semakin banyak gugus hidroksil yang mengikat air sehingga viskositas adonan akan meningkat. Viskositas yang meningkat akan menghambat masuknya udara dalam adonan selama proses churning. Selain itu pembentukan matriks akan semakin besar sehingga pemerangkapan udara akan kurang optimum.

\section{Rasa}

Hasil uji ANOVA pada $\alpha=5 \%$ menunjukkan bahwa terdapat pengaruh nyata perbedaan konsentrasi jahe dan konsentrasi guar gum terhadap kesukaan rasa es krim jahe. Uji ANOVA kemudian dilanjutkan dengan uji DMRT untuk mengetahui perlakuan yang memberikan perbedaan nyata. Penambahan jahe berfungsi sebagai pemberi flavor pada es krim jahe, sehingga kesukaan terhadap rasa es krim jahe sangat tergantung pada konsentrasi jahe yang digunakan.

Jahe memiliki kandungan senyawa volatil dan non-volatil. Senyawa volatil pada jahe yaitu minyak atsiri yang berperan dalam memberi aroma khas jahe. Kadar minyak atsiri pada jahe gajah sebesar 0,82$1,66 \%$, sedangkan jahe emprit sebesar $1,50-3,50 \%$. Sedangkan senyawa nonvolatil pada jahe yaitu oleoresin yang mengandung senyawa aktif gingerol yang berperan dalam memberi rasa khas jahe atau efek pungensi (karakteristik pedas, tajam dan sensasi menyengat). Oleh karena itu semakin tinggi konsentrasi jahe yang digunakan maka efek pungensi pada es krim akan semakin dominan. Bahan pengental seperti guar gum memiliki gugus hidroksil yang dapat mengikat air, sehingga rasa atau efek pungensi dari jahe akan semakin terasa. 


\section{Mouthfeel}

Pengujian parameter mouthfeel dapat diartikan sebagai pengujian tekstur es krim saat berada di mulut. Hasil uji ANOVA menunjukkan adanya pengaruh nyata akibat perbedaan konsentrasi jahe dan penstabil guar gum terhadap kesukaan mouthfeel es krim jahe. Jika dilihat dari perlakuan konsentrasi jahe yang berbeda dalam konsentrasi guar gum yang sama, terdapat peningkatan nilai rata-rata kesukaan mouthfeel pada konsentrasi jahe $20 \%$ ke $35 \%$, namun terjadi penurunan nilai kesukaan dari konsentrasi jahe 35\% ke $50 \%$. Hal ini dikarenakan pada sari jahe terdapat pati yang dapat meningkatkan viskositas adonan es krim. Meningkatnya viskositas membuat air bebas pada adonan semakin berkurang, sehingga kristal es yang dihasilkan es krim lebih kecil dan membuat es krim lebih lembut di mulut.

Pada konsentrasi jahe 50\% mengalami penurunan tingkat kesukaan karena kandungan pati dari sari jahe semakin tinggi yang menyebabkan viskositas adonan es krim meningkat sehingga es krim terasa "berat" saat dimakan dan saat melumer akan terasa sangat kental. Semakin tinggi penambahan konsentrasi guar gum menyebabkan semakin tinggi tingkat kesukaan mouthfeel. Hal ini dikarenakan penambahan penstabil guar gum dapat meningkatkan viskositas dan stabilitas busa es krim. Busa pada campuran es krim cenderung lebih stabil dengan penambahan guar gum karena mengakibatkan penggabungan atau pengikatan silang rantai-rantai polimer pada campuran es krim, sehingga terbentuk suatu jala tiga dimensi bersambungan. Jala ini menangkap air di dalamnya dan membentuk struktur yang kuat dan kaku secara optimal. Semakin banyak air bebas yang terperangkap dapat mencegah terbentuknya kristal es yang besar sehingga melembutkan tekstur es krim (Clarke, 2004).

\section{KESIMPULAN}

Perbedaan konsentrasi jahe maupun konsentrasi stabilizer guar gum berpengaruh pada laju pelelehan, overrun dan organoleptik es krim jahe (rasa dan mouthfeel). Konsentrasi jahe maupun konsentrasi stabilizer guar gum yang semakin tinggi menyebabkan penurunan laju leleh dan overrun es krim jahe. Kesukaan terhadap rasa es krim jahe paling tinggi pada konsentrasi jahe $20 \%$ (P1) yaitu pada level agak suka. Kesukaan terhadap mouthfeel es krim jahe paling tinggi pada konsentrasi jahe 35\% (P2) yaitu pada level agak suka. Kesukaan terhadap rasa es krim jahe paling tinggi pada konsentrasi stabilizer guar gum $0,2 \%$ (K1) yaitu pada level agak suka. Kesukaan terhadap mouthfeel es krim jahe paling tinggi pada konsentrasi stabilizer guar gum $0,6 \%$ (K3) yaitu pada level agak suka..

\section{DAFTAR PUSTAKA}

Clarke, C. 2004. The Science of Ice Cream. United Kindom: The Royal Society of Chemistry. Cornwahlf.

DeMan, J.M. 1999. Principles of Food Chemistry $3^{\text {rd }}$ Edition. Maryland: Aspen Publisher, Inc.

Elisabeth, D. A. A., M. A. Widyaningsih dan I. K. Karaida. 2007. Pemanfaatan Umbi Ubi Jalat sebagai Bahan Baku Pembuatan Es Krim. ). Bali: Balai Pengkajian Teknologi Pertanian (BPTP).

Febriyanti, S dan Yunianta. 2015. Pengaruh Konsentrasi Karagenan dan Rasio Sari Jahe Emprit (Zingiber officinale var. Rubrum) terhadap Sifat Fisik, Kimia dan Organoleptik Jelly Drink Jahe. Jurnal Pangan dan Agroindustri, 3(2): 542-550.

Goraya, R. K., D. K. Gabbi and U. Bajwa. 2017. Physicochemical, Melting and Sensory Properties of Ice Cream incorporating Processed Ginger (Zingiber officinale). International 
Journal of Diary Technology, Punjab Agricultural University, India.

Hakim, A. R. dan A. Chamidah. 2013. Aplikasi Gum Arab dan Dekstrin sebagai Bahan Pengikat Protein Ekstrsk Kepala Udang. Jurnal, Universitas Brawijaya Malang.

Jimenez-Florez R., N.J. Klipfel dan J. Tobias. 1993. Ice Cream and Frozen Dessert. New York: VCH Publishers.

Koswara, S., A. Diniari dan Sumarto. 2012. Panduan Proses Produksi Minuman Jahe Merah Instan. Lembaga Penelitian dan Pengabdian kepada Masyarakat. Institut Pertanian Bogor.

Muse, M.R. and R.W. Hartel. 2004. Ice Cream Structural Element that Affect Melting Rate and Hardness. Journal Diary Science. 87(1): 1-10.

Padaga, M. C. H., L. Hakim dan Purwadi. 2012. Penambahan Gum Guar pada Pembuatan Es Krim Instan Ditinjau dari Viskositas, Overrun dan Kecepatan Meleleh. http://www.fapet.ub.ac.id.com (29 2018). 